\title{
Exercise Is Associated With Reduction in the Anxiogenic Effect of mCPP on Acoustic Startle
}

\author{
James H. Fox, Sayamwong E. Hammack, and William A. Falls \\ University of Vermont
}

\begin{abstract}
Voluntary exercise has been associated with reduced anxiety across several animal models. Manipulation of central 5-HT can alter anxiety-like behaviors and administration of the 5-HT agonist metachlorophenylpiperazine $(\mathrm{mCPP})$ increases anxiety in rodents and humans. To examine whether the anxiolytic effect of exercise is associated with an alteration in 5-HT systems, we examined the anxiogenic effect of mCPP in exercising and nonexercising mice. C57BL/6J mice were given 2 weeks of free access to either a functioning or nonfunctioning running wheel. Mice were then tested for acoustic startle following systemic injection of either $0,0.1,0.3$, or $1 \mathrm{mg} / \mathrm{kg}$ of $\mathrm{mCPP}$. Consistent with its anxiogenic properties, mCPP produced a dose-dependent increase in acoustic startle in nonexercising mice. However, this anxiogenic effect was blunted in exercising mice. These findings suggest that exercise may help to reduce anxiety by altering 5 -HT systems, perhaps by down-regulating postsynaptic $5 \mathrm{HT} 2 \mathrm{~B} / 2 \mathrm{C}$ receptors.
\end{abstract}

Keywords: anxiety, serotonin, meta-chlorophenylpiperazine, wheel running, 5-HT2C receptor

It is well known that physical activity (i.e., exercise) benefits the cardiovascular system and thereby improves physical health. There is now a growing evidence that exercise also benefits the brain (Cotman \& Berchtold, 2002; Cotman \& Engesser-Cesar, 2002) and improves cognitive and emotional health (Dishman et al., 2006; Friedland et al., 2001; Hillman, Belopolsky, Snook, Kramer, \& McAuley, 2004; Laurin, Verreault, Lindsay, MacPherson, \& Rockwood, 2001; Manger \& Motta, 2005). In humans, physical exercise is associated with a lower risk of cognitive impairment, dementia and Alzheimer's disease (Friedland et al., 2001; Laurin et al., 2001) and has been associated with improvements in attention (Hillman et al., 2004). Consistent with these effects, voluntary exercise in rodents improves learning and memory across several tasks and can mitigate cognitive decline in senescent mice (Baruch, Swain, \& Helmstetter, 2004; Christie et al., 2005; Fordyce \& Farrar, 1991; Fordyce, Starnes, \& Farrar, 1991; Fordyce \& Wehner, 1993; Radak et al., 2001; Samorajski et al., 1985; van Praag, Christie, Sejnowski, \& Gage, 1999a; van Praag, Chunm, \& Gage, 2005; van Praag, Kempermann, \& Gage, 1999b, 2000). Although the exact mechanisms by which exercise benefits the brain are unclear (Cotman \& Berchtold, 2002; Dishman et al., 2006), voluntary exercise in rodents is associated with neurogenesis, increased neuronal survival (Brown et al., 2003; Farmer et al., 2004; van Praag et al., 1999a, 2005; van Praag et al., 1999b, 2000), capillary growth and increased vascular flow (Black, Isaacs, Anderson, Alcantara, \& Greenough, 1990; Isaacs, Anderson, Alcantara, Black, \& Greenough, 1992; Swain et al., 2003), increased expression of neurotrophins (Gomez-Pinilla, Ying, Roy, Molteni, \& Edgerton, 2002; Neeper, Gomez-Pinilla, Choi, \& Cotman, 1995,

James H. Fox, Sayamwong E. Hammack, and William A. Falls, Department of Psychology, University of Vermont.

Correspondence concerning this article should be addressed to William A. Falls, Department of Psychology, University of Vermont, 2 Colchester Avenue, Burlington, VT 05405. E-mail: william.falls@uvm.edu
1996; Vaynman, Ying, \& Gomez-Pinilla, 2004a, 2004b), changes in gene expression (Tong, Shen, Perreau, Balazs, \& Cotman, 2001) and signaling molecules (Shen, Tong, Balazs, \& Cotman, 2001), and changes in serotonin (Greenwood, Foley, Burhans, Maier, \& Fleshner, 2005; Greenwood et al., 2003a), norepinephrine and Gamma-aminobutyric acid (GABA) (Dunn, Reigle, Youngstedt, Armstrong, \& Dishman, 1996; Overton et al., 1991).

Physical exercise also affects emotional health. In humans, exercise has been associated with improvement in treatment outcomes for both depression and anxiety (Dunn, Trivedi, \& O'Neal, 2001; Fox, 1999; Morgan \& Goldstein, 1987; Salmon, 2001; Scully, Kremer, Meade, Graham, \& Dudgeon, 1998) and may be particularly effective in managing posttraumatic stress disorder (PTSD) (Manger \& Motta, 2005). Voluntary exercise in rodents has been shown to improve immunological and behavioral responses following stress (Dishman, 1997; Dunn et al., 1996; Fleshner, 2000, 2005; Kennedy, Smith, \& Fleshner, 2005; Moraska \& Fleshner, 2001; Soares et al., 1999) and to produce a reduction in anxiety as measured in the open field (Dishman et al., 1996), elevated plus maze and the light-dark box (Binder, Droste, Ohl, \& Reul, 2004). Consistent with this, we have recently shown that voluntary exercise in $\mathrm{C} 57 \mathrm{BL} / 6 \mathrm{~J}$ mice produces a robust anxiolytic effect as evidenced by a reduction in startle amplitude, increased time spent in the center of an open field, decreased stress-induced hyperthermia and increased social interaction (Detroy, Duffy, Guignon, \& Falls, 2005).

Any number of adaptive changes in the brain could contribute to the anxiolytic effect of voluntary exercise (Dishman et al., 1996, 1997; Dunn et al., 1996; Soares et al., 1999). However, given the important role of serotonin (5-HT) in anxiety [see (Handley, 1995) for review] and in the etiology and treatment of anxiety disorders, it is likely that changes in central 5-HT functioning play some role in the anxiolytic effects of exercise (Greenwood et al., 2003b).

Metachlorophenylpiperazine (mCPP) is anxiogenic in humans (Feuchtl et al., 2004; Gatch, 2003; Graeff, Garcia-Leal, Del-Ben, 
\& Guimaraes, 2005) and rodents (Abrams et al., 2005; BilkeiGorzo, Gyertyan, \& Szabados, 1996; Cornelio \& Nunes-de-Souza, 2007; Graeff, Guimaraes, De Andrade, \& Deakin, 1996; Risbrough \& Geyer, 2005) and has been associated with activation of brain areas that are known to participate in the regulation of anxiety-related behaviors (Singewald, Salchner, \& Sharp, 2003; Thompson \& Rosen, 2006). Because exercise in rodents is anxiolytic and has been associated with alterations in central 5-HT functioning (Greenwood et al., 2004), we tested whether exercise in mice would be associated with a decrease in the anxiogenic effect of mCPP. C57BL/6J mice were given 2 weeks of voluntary access to a running wheel. Following this, mice were injected with $\mathrm{mCPP}(0,0.1,0.3$, and $1.0 \mathrm{mg} / \mathrm{kg}$, ip) and tested for acoustic startle. The acoustic startle response is a sensitive measure of anxiety (Davis, Falls, Campeau, \& Kim, 1993; Walker, Toufexis, \& Davis, 2003): drugs and environmental conditions known to increase anxiety increase acoustic startle (Grillon, Pellowski, Merikangas, \& Davis, 1997; Lee \& Davis, 1997b; Walker \& Davis, 1997) whereas drugs and environmental conditions known to decrease anxiety decrease acoustic startle (Davis et al., 1993; Koch, Schmid, \& Schnitzler, 1996; Schweimer, Fendt, \& Schnitzler, 2005). If exercise is associated with an alteration in 5-HT systems, then mice given access to a running wheel will show a blunted anxiogenic response to $\mathrm{mCPP}$.

\section{Method}

\section{Subjects}

Male C57BL/6J mice $(n=59)$ were obtained from Jackson Laboratories (Bar Harbor, Maine). Mice were housed in groups of four and maintained on a 12-h light/dark cycle (lights on at 0700 hours). Food and water were available ad libitum. Cages of mice were randomly assigned to exercise or nonexercising groups. Exercise groups were given free access to a functioning running wheel while nonexercising groups had access to a locked, nonfunctioning running wheel. Mice were housed for 2 weeks with the running wheel before the beginning of experiments. We have previously shown (Detroy et al., 2005) that the total distance run in 24 hours per cage is $18.05 \mathrm{~km}( \pm 0.3 \mathrm{~km}$, approximate average of $4.5 \mathrm{~km}$ per mouse). This is consistent with published reports indicating that $\mathrm{C} 57 \mathrm{BL} / 6 \mathrm{~J}$ given free access to a running wheel will run approximately 4 to $5 \mathrm{~km}$ in a 24-h period (Droste et al., 2003; Harri et al., 1999). Furthermore, a detailed video analysis of night cycle running in a sample of four cages revealed that each individual mouse runs on average $25 \%$ of the total time (range 17 and $38 \%$ ). There are also no differences in body weight between exercising and nonexercising mice (Droste et al., 2003; Harri et al., 1999).

\section{Drugs}

mCPP $\mathrm{HCl}$ (Sigma-Aldrich, St. Louis, MO) was mixed fresh in physiological saline for each injection day. Doses of $0,0.1 \mathrm{mg} / \mathrm{kg}$, and $0.3 \mathrm{mg} / \mathrm{kg}$ and $1.0 \mathrm{mg} / \mathrm{kg}$ were administered intraperitoneal in a volume of $10 \mathrm{ml} / \mathrm{kg}$. Injections were given 15 minutes before the test for acoustic startle (Risbrough \& Geyer, 2005).

\section{Apparatus}

Acoustic startle was measured in eight individual sound attenuating cubicles measuring $58(\mathrm{~W}) \times 32(\mathrm{D}) \times 55(\mathrm{H}) \mathrm{cm}$. Each cubicle was lined with black, sound absorbing foam with no internal source of light. Each cubicle contained a stabilimeter device consisting of a load cell platform onto which the behavioral chamber was mounted. The chamber was constructed of clear acrylic, cylindrical in shape, $12.5 \mathrm{~cm}$ in length, with an inner diameter of $5 \mathrm{~cm}$ (Med Associates, Georgia, VT). Startle responses were transduced by the load cell, amplified, and digitized over a range of 0 to 4,096 units. Startle stimuli were $20 \mathrm{~ms}$ bursts of white noise (10 each at 95, 100, and $105 \mathrm{~dB}$ ) provided through Radio Shack Supertweeters, one located in each sound attenuating cubicles $10 \mathrm{~cm}$ behind each behavioral chamber.

Data collection and the control and sequencing of all stimuli were controlled by Med-Associates startle reflex hardware and software (Georgia, VT). Startle amplitude was defined as the largest peak to trough value within $100 \mathrm{~ms}$ after the onset of the startle stimulus.

\section{Procedure}

The experiment was carried out with a within subjects design in which each mouse within an exercising group was given each of the four doses of mCPP $(0,0.1,0.3$, and $1 \mathrm{mg} / \mathrm{kg})$. The order of doses for each mouse was determined using a Latin Square design such that on each test day an equal number of mice received each dose.

Mice were transported to the lab from the colony in their home cage. Mice were removed from their cage, weighed, and injected with one of four doses of mCPP. Fifteen minutes later, mice were placed in the startle apparatus. After a 5-min acclimation period during which no stimuli were administered, the mice were given the first of 30 noise burst startle stimuli (10 each at 95, 100, and $105 \mathrm{~dB}$ ) presented in a pseudorandom order with the constraint that each startle intensity occur once in each block of three stimuli. The intertrial interval was 60 seconds. This procedure was repeated three additional times until each mouse had been given each dose of mCPP. The interval between successive doses of mCPP (i.e., between successive startle tests) was 48 hours.

\section{Statistical Analysis}

Mean startle amplitude was computed for each mouse at each dose. The data were analyzed with a repeated measures analysis of variance (ANOVA) with group (exercising or nonexercising) and dose $(0,0.1,0.3,1.0 \mathrm{mg} / \mathrm{kg})$ as independent factors and startle amplitude as the dependent factor. Post hoc analyses with Newman-Keuls paired $t$ tests were used to test for differences within groups across the doses of mCPP (Hays, 1988).

\section{Results}

As we have previously reported (Detroy et al., 2005), mice given access to a running wheel (exercising group) exhibited lower acoustic startle amplitude than mice given access to a locked (i.e., nonfunctioning) running wheel (nonexercising group) (Figure 1, 0 $\mathrm{mg} / \mathrm{kg} \mathrm{mCPP).} \mathrm{mCPP} \mathrm{dose} \mathrm{dependently} \mathrm{facilitated} \mathrm{acoustic} \mathrm{startle}$ in nonexercising mice. However, this effect was blunted in exercising mice. In fact, only the highest dose of mCPP facilitated startle in exercising mice. 
ANOVA revealed significant main effects of group (exercising vs. nonexercising, $F(1,57)=33, p<.05)$ and mCPP dose $(F(3$, $171)=30.9, p<.05)$ as well as a significant dose by group interaction, $F(3,171)=2.93, p<.05$. The significant interaction was followed up with lower order ANOVAs for each group. mCPP produced a dose dependent facilitation in startle in nonexercising mice $F(3,171)=2.93, p<.05$. Each dose of mCPP elevated startle above the $0 \mathrm{mg} / \mathrm{kg}$ dose (Student-Newman-Keuls test, $p \mathrm{~s}<$ $.05)$. In contrast, only the highest dose of mCPP significantly facilitated startle $(1.0 \mathrm{mg} / \mathrm{kg})$ in exercising mice $(p<.05)$.

\section{Discussion}

Several clinical studies have suggested an anxiolytic effect of regular exercise in humans (Dunn et al., 2001; Fox, 1999; Manger \& Motta, 2005; Morgan \& Goldstein, 1987; Salmon, 2001; Scully et al., 1998); however, in rodents the anxiolytic effects of exercise has been somewhat more variable. In studies allowing animals voluntary access to a running wheel there are reports of anxiolytic effects (Binder et al., 2004; Dishman et al., 1996, 1997), no effects (Pietropaolo, Feldon, Alleva, Ciruli, \& Yee, 2006) or increases in anxiety-like behavior following exercise (Burghardt, Fulk, Hand, $\&$ Wilson, 2004). Although these inconsistencies may be because of any number of experimental variables, including differences in species (rat or mouse), sex, housing conditions (e.g., single vs. grouped housed), duration of exercise and anxiety model, they point to the need for continued assessment of the putative anxiolytic effects of exercise in animal models. In this study, we show that 2 weeks of voluntary exercise reduced acoustic startle amplitude and blunted the startle-enhancing effect of the anxiogenic drug mCPP. Because anxiolytic treatments decrease acoustic startle (Grillon et al., 1997; Lee \& Davis, 1997b; Walker \& Davis, 1997), whereas anxiogenic treatments increase acoustic startle (Davis et al., 1993; Koch et al., 1996; Schweimer et al., 2005), we interpret these data as being consistent with an anxiolytic effect of voluntary exercise. The fact that 2 weeks of exercise was sufficient to produce an anxiolytic effect is interesting in light of the fact that studies typically allow rodents to run for up to 6 weeks. Unpublished data from our lab suggests that 1 week, but not 3 days, of exercise is sufficient to reduce startle amplitude and the reduction in startle amplitude persists as long as the mice are allowed to run (up to 12 weeks). Clearly much more work is needed examining how the duration of exercise influences the reduction in anxiety (see Berchtold, Chinn, Chou, Kesslak, \& Cotman, 2005).

$\mathrm{mCPP}$ is a 5-HT agonist, and because voluntary exercise was associated with a blunted effect of $\mathrm{mCPP}$, this suggests voluntary exercise exerts its anxiolytic effect in part through altering central 5-HT function (Greenwood et al., 2005, 2003a). In humans, exercise has also been shown to blunt the effect of mCPP. Individuals completing a 10-week exercise regimen and subsequently challenged with an oral dose of mCPP showed a decreased cortisol response as compared to their response in a preexercise challenge (Broocks et al., 2001). mCPP is thought to mediate its anxiogenic effects through actions at the 5- $\mathrm{HT}_{2 \mathrm{C}}$ receptor (Campbell \& Merchant, 2003; Curzon \& Kennett, 1990; Gibson, Barnfield, \& Curzon, 1994; Kennett, Whitton, Shah, \& Curzon, 1989; Kennett et al., 1996; Wood, 2003). With this, and because the cortisol response to $\mathrm{mCPP}$ is largely mediated by $5-\mathrm{HT}_{2 \mathrm{~B} / 2 \mathrm{C}}$ receptors (Broocks et al., 2001), Broocks and colleagues hypothesize that exercise leads to a down-regulation of central $5-\mathrm{HT}_{2 \mathrm{~B} / 2 \mathrm{C}}$ receptors. Although mCPP has high affinity for $5-\mathrm{HT}_{2 \mathrm{C}}$ receptors, it also binds to several other 5-HT receptor subtypes (Hoyer et al., 1994; Porter et al., 1999). Therefore, based on the present data, and without the benefit of highly selective antagonist studies examining the principal receptor subtypes responsible for augmenting acoustic startle, it is currently unknown whether mCPP enhances startle by actions at $5-\mathrm{HT}_{2 \mathrm{C}}$ receptors or another 5-HT receptor

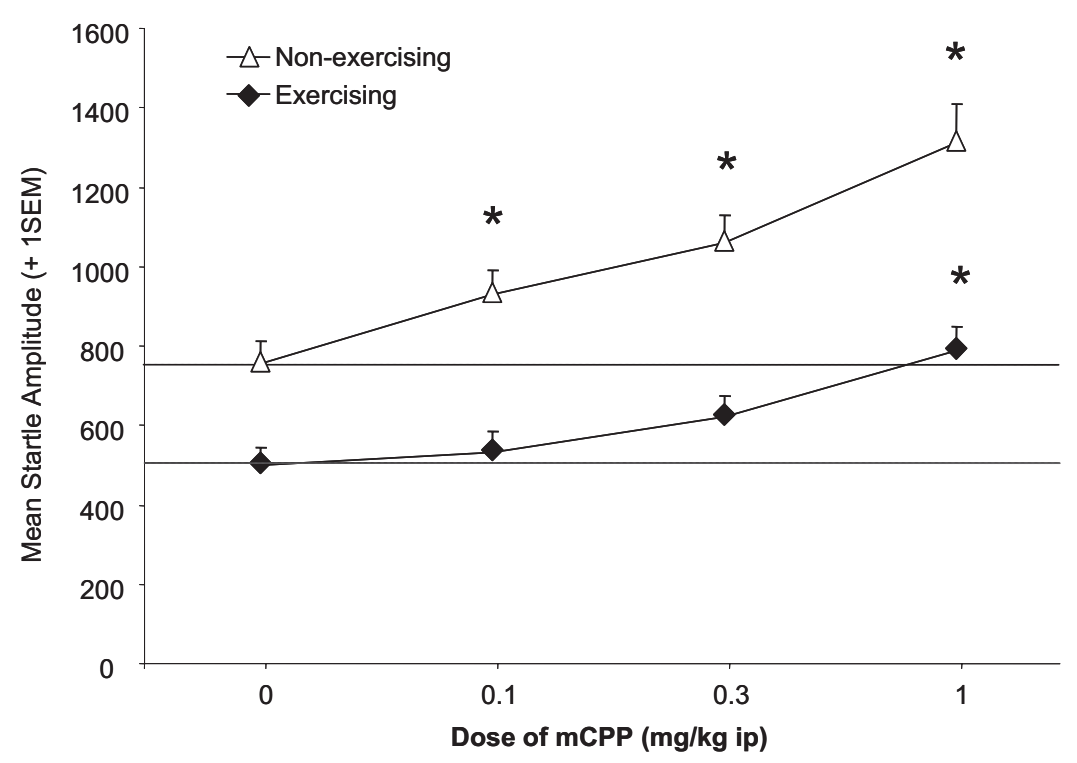

Figure 1. The 5-HT receptor agonist mCPP dose dependently increases acoustic startle amplitude in nonexercising mice. Dashed line represents startle amplitude following vehicle injection $(0 \mathrm{mg} / \mathrm{kg}) .{ }^{*} \mathrm{Newman}-\mathrm{Keuls}$ Pairwise Comparison versus $0 \mathrm{mg} / \mathrm{kg}, p<.05$. 
subtype. Therefore, we can only speculate the anxiolytic effect of exercise on acoustic startle is mediated by alterations in $5-\mathrm{HT}_{2 \mathrm{C}}$ receptors.

Greenwood et al. (2003) have provided further evidence that voluntary exercise alters central 5-HT function. In their experiments, 6 weeks of voluntary exercise in rats was associated with an up-regulation of mRNA for 5-HT $1 \mathrm{~A}$ somatodentritic autoreceptors in the dorsal raphe nucleus (DRN) (Greenwood et al., 2003b). If the up-regulation of mRNA for $5-\mathrm{HT}_{1 \mathrm{~A}}$ somatodentritic autoreceptors results in an up-regulation of receptor protein, additional $5-\mathrm{HT}_{1 \mathrm{~A}}$ autoreceptors would decrease DRN activity by enhancing autoinhibition of DRN cell firing. This, in turn, should decrease 5-HT release in DRN projection areas that are known to play a role in anxiety-related behaviors. Consistent with this, Dishman and colleagues (Dishman et al., 1997) have reported that voluntary exercise in rats was associated with decreased shock-induced elevation in the 5-HT metabolite 5-hydroxyindole acetic acid in the hippocampus and amygdala suggesting that exercise decreased 5-HT function in these DRN targets associated with anxiety-like behavior. It is interesting to note that treadmill (i.e., forced) exercise has been shown to increase 5-HT release in the hippocampus, frontal cortex, and spinal cord (Bequet, Gomez-Merino, Berthelot, \& Guezennec, 2001, 2002; Gerin, Legrand, \& Privat, 1994; Gomez-Merino, Bequet, Berthelot, Chennaoui, \& Guezennec, 2001; Meeusen et al., 1996). Treadmill running appears to be qualitatively different from voluntary exercise and has been argued to be more akin to stress (Dunn et al., 1996). In this light, it is interesting that treadmill running may also produce qualitatively different effect on the 5-HT system.

In addition to the documented exercise-induced changes in presynaptic 5-HT function, it is possible that exercise additionally affects postsynaptic 5-HT function. There is substantial evidence implicating a role for the bed nucleus of the stria terminalis (BNST) in anxiety-related behavior. For example, lesions of the BNST reduce anxious responding to intracerebroventricular corticotropin-releasing factor (CRF) (Lee \& Davis, 1997a), bright lights (Walker \& Davis, 2002), uncontrollable shock (Hammack, Richey, Watkins, \& Maier, 2004), and exposure to predator odor (Fendt, Endres, \& Apfelbach, 2003). The BNST receives direct projections from the DRN and systemic injection of mCPP increases cFos expression in the BNST (Singewald et al., 2003). Moreover, direct intra-BNST infusion of the 5-HT ${ }_{1-\text { like/7 }}$ agonist 5-carboxytryptamine (5-CT) produces an anxiolytic-like effect on acoustic startle (Levita et al., 2004). In an unpublished study we have shown that direct infusion of low doses of mCPP into the BNST increases acoustic startle in mice. Hence, we suggest that the anxiolytic effect of voluntary exercise may be due in part to a decrease in 5-HT mediated activity in the BNST.

\section{References}

Abrams, J. K., Johnson, P. L., Hay-Schmidt, A., Mikkelsen, J. D., Shekhar, A., \& Lowry, C. A. (2005). Serotonergic systems associated with arousal and vigilance behaviors following administration of anxiogenic drugs. Neuroscience, 133, 983-997.

Baruch, D. E., Swain, R. A., \& Helmstetter, F. J. (2004). Effects of exercise on Pavlovian fear conditioning. Behavioral Neuroscience, 118, 1123-1127.

Bequet, F., Gomez-Merino, D., Berthelot, M., \& Guezennec, C. Y. (2001). Exercise-induced changes in brain glucose and serotonin revealed by microdialysis in rat hippocampus: Effect of glucose supplementation. Acta Physiologica Scandinavica, 173, 223-230.

Bequet, F., Gomez-Merino, D., Berthelot, M., \& Guezennec, C. Y. (2002). Evidence that brain glucose availability influences exercise-enhanced extracellular 5-HT level in hippocampus: A microdialysis study in exercising rats. Acta Physiologica Scandinavica, 176, 65-69.

Berchtold, N. C., Chinn, G., Chou, M., Kesslak, J. P., \& Cotman, C. W. (2005). Exercise primes a molecular memory for brain-derived neurotrophic factor protein induction in the rat hippocampus. Neuroscience, 133, 853-861.

Bilkei-Gorzo, A., Gyertyan, I., \& Szabados, T. (1996). mCPP-induced anxiety: A potential new method for screening anxiolytic activity. Neurobiology (Budapest), 4, 253-255.

Binder, E., Droste, S. K., Ohl, F., \& Reul, J. M. (2004). Regular voluntary exercise reduces anxiety-related behaviour and impulsiveness in mice. Behavioural Brain Research, 155, 197-206.

Black, J. E., Isaacs, K. R., Anderson, B. J., Alcantara, A. A., \& Greenough, W. T. (1990). Learning causes synaptogenesis, whereas motor activity causes angiogenesis, in cerebellar cortex of adult rats. Proceedings of the National Academy of Sciences, USA, 87, 5568-5572.

Broocks, A., Meyer, T., Gleiter, C. H., Hillmer-Vogel, U., George, A., Bartmann, U., \& Bandelow, B. (2001). Effect of aerobic exercise on behavioral and neuroendocrine responses to meta-chlorophenylpiperazine and to ipsapirone in untrained healthy subjects. Psychopharmacology, 155, 234-241.

Brown, J., Cooper-Kuhn, C. M., Kempermann, G., Van Praag, H., Winkler, J., Gage, F. H., \& Kuhn, H. G. (2003). Enriched environment and physical activity stimulate hippocampal but not olfactory bulb neurogenesis. European journal of Neuroscience, 17, 2042-2046.

Burghardt, P. R., Fulk, L., Hand, G., \& Wilson, M. A. (2004). The effects of chronic treadmill and wheel running on behavior in rats. Brain Research, 1019, 84-96.

Campbell, B. M., \& Merchant, K. M. (2003). Serotonin 2C receptors within the basolateral amygdala induce acute fear-like responses in an open-field environment. Brain Research, 993, 1-9.

Christie, B. R., Swann, S. E., Fox, C. J., Froc, D., Lieblich, S. E., Redila, V., \& Webber, A. (2005). Voluntary exercise rescues deficits in spatial memory and long-term potentiation in prenatal ethanol-exposed male rats. European journal of Neuroscience, 21, 1719-1726.

Cornelio, A. M., \& Nunes-de-Souza, R. L. (2007). Anxiogenic-like effects of mCPP microinfusions into the amygdala (but not dorsal or ventral hippocampus) in mice exposed to elevated plus-maze. Behavioural Brain Research, 178, 82-89.

Cotman, C. W., \& Berchtold, N. C. (2002). Exercise: A behavioral intervention to enhance brain health and plasticity. Trends in Neurosciences, $25,295-301$.

Cotman, C. W., \& Engesser-Cesar, C. (2002). Exercise enhances and protects brain function. Exercise \& Sport Sciences Reviews, 30, 75-79.

Curzon, G., \& Kennett, G. A. (1990). m-CPP: A tool for studying behavioural responses associated with 5-HT1c receptors. Trends in Pharmacological Sciences, 11, 181-182.

Davis, M., Falls, W. A., Campeau, S., \& Kim, M. (1993). Fear-potentiated startle: A neural and pharmacological analysis. Behavioral Brain Research, 58, 175-198.

Detroy, E., Duffy, A., Guignon, M., \& Falls, W. (2005). Voluntary wheel running reduces startle amplitude and enhances conditioned fear. 35th Annual Meeting of the Society for Neuroscience, Washington, DC, 30.

Dishman, R. K. (1997). Brain monoamines, exercise, and behavioral stress: Animal models. Medicine \& Science in Sports \& Exercise, 29, 63-74.

Dishman, R. K., Berthoud, H. R., Booth, F. W., Cotman, C. W., Edgerton, V. R., Fleshner, M. R., et al. (2006). Neurobiology of exercise. Obesity, $14,345-356$.

Dishman, R. K., Dunn, A. L., Youngstedt, S. D., Davis, J. M., Burgess, M. L., Wilson, S. P., et al. (1996). Increased open field locomotion and 
decreased striatal GABAa binding after activity wheel running. Physiology and Behavior, 60, 699-705.

Dishman, R. K., Renner, K. J., Youngstedt, S. D., Reigle, T. G., Bunnell, B. N., Burke, K. A., et al. (1997). Activity wheel running reduces escape latency and alters brain monoamine levels after footshock. Brain Research Bulletin, 42, 399-406.

Droste, S. K., Gesing, A., Ulbricht, S., Muller, M., Linthorst, A., \& Reul, J. M. (2003). Effects of long-term voluntary exercise on the mouse hypothalamic-pituitary-adrenal axis. Endocrinology, 144, 3012-3023.

Dunn, A. L., Reigle, T. G., Youngstedt, S. D., Armstrong, R. B., \& Dishman, R. K. (1996). Brain norepinephrine and metabolites after treadmill training and wheel running. Medicine \& Science in Sports \& Exercise, 28, 204-209.

Dunn, A. L., Trivedi, M. H., \& O'Neal, H. A. (2001). Physical activity dose-response effects on outcomes of depression and anxiety. Medicine \& Science in Sports \& Exercise, 33(Suppl), S587-597; discussion 609-510.

Farmer, J., Zhao, X., van Praag, H., Wodtke, K., Gage, F. H., \& Christie, B. R. (2004). Effects of voluntary exercise on synaptic plasticity and gene expression in the dentate gyrus of adult male Sprague-Dawley rats in vivo. Neuroscience, 124, 71-79.

Fendt, M., Endres, T., \& Apfelbach, R. (2003). Temporary inactivation of the bed nucleus of the stria terminalis but not of the amygdala blocks freezing induced by trimethylthiazoline, a component of fox feces. Journal of Neuroscience, 23, 23-28.

Feuchtl, A., Bagli, M., Stephan, R., Frahnert, C., Kolsch, H., Kuhn, K. U., $\&$ Rao, M. L. (2004). Pharmacokinetics of m-chlorophenylpiperazine after intravenous and oral administration in healthy male volunteers: Implication for the pharmacodynamic profile. Pharmacopsychiatry, 37, $180-188$.

Fleshner, M. (2000). Exercise and neuroendocrine regulation of antibody production: Protective effect of physical activity on stress-induced suppression of the specific antibody response [see comment]. International Journal of Sports Medicine, 21, 14-19.

Fleshner, M. (2005). Physical activity and stress resistance: Sympathetic nervous system adaptations prevent stress-induced immunosuppression. Exercise \& Sport Sciences Reviews, 33, 120-126.

Fordyce, D. E., \& Farrar, R. P. (1991). Enhancement of spatial learning in F344 rats by physical activity and related learning-associated alterations in hippocampal and cortical cholinergic functioning. Behavioural Brain Research, 46, 123-133.

Fordyce, D. E., Starnes, J. W., \& Farrar, R. P. (1991). Compensation of the age-related decline in hippocampal muscarinic receptor density through daily exercise or underfeeding. Journal of Gerontology, 46, B245-248.

Fordyce, D. E., \& Wehner, J. M. (1993). Physical activity enhances spatial learning performance with an associated alteration in hippocampal protein kinase $\mathrm{C}$ activity in $\mathrm{C} 57 \mathrm{BL} / 6$ and DBA/2 mice. Brain Research, 619, 111-119.

Fox, K. R. (1999). The influence of physical activity on mental well-being. Public Health Nutrition, 2, 411-418.

Friedland, R. P., Fritsch, T., Smyth, K. A., Koss, E., Lerner, A. J., Chen, C. H., et al. (2001). Patients with Alzheimer's disease have reduced activities in midlife compared with healthy control-group members. Proceedings of the National Academy of Sciences, USA, 98, 3440-3445.

Gatch, M. B. (2003). Discriminative stimulus effects of $\mathrm{m}$-chlorophenylpiperazine as a model of the role of serotonin receptors in anxiety. Life Sciences, 73, 1347-1367.

Gerin, C., Legrand, A., \& Privat, A. (1994). Study of 5-HT release with a chronically implanted microdialysis probe in the ventral horn of the spinal cord of unrestrained rats during exercise on a treadmill. Journal of Neuroscience Methods, 52, 129-141.

Gibson, E. L., Barnfield, A. M., \& Curzon, G. (1994). Evidence that mCPP-induced anxiety in the plus-maze is mediated by postsynaptic 5-HT2C receptors but not by sympathomimetic effects. Neuropharmacology, 33, 457-465.
Gomez-Merino, D., Bequet, F., Berthelot, M., Chennaoui, M., \& Guezennec, C. Y. (2001). Site-dependent effects of an acute intensive exercise on extracellular 5-HT and 5-HIAA levels in rat brain. Neuroscience Letters, 301, 143-146.

Gomez-Pinilla, F., Ying, Z., Roy, R. R., Molteni, R., \& Edgerton, V. R. (2002). Voluntary exercise induces a BDNF-mediated mechanism that promotes neuroplasticity. Journal of Neurophysiology, 88, 2187-2195.

Graeff, F. G., Garcia-Leal, C., Del-Ben, C. M., \& Guimaraes, F. S. (2005). Does the panic attack activate the hypothalamic-pituitary-adrenal axis? Anais Da Academia Brasileira de Ciencias, 77, 477-491.

Graeff, F. G., Guimaraes, F. S., De Andrade, T. G., \& Deakin, J. F. (1996) Role of 5-HT in stress, anxiety, and depression. Pharmacology, Biochemistry \& Behavior, 54, 129-141.

Greenwood, B. N., Foley, T. E., Burhans, D., Maier, S. F., \& Fleshner, M. (2005). The consequences of uncontrollable stress are sensitive to duration of prior wheel running. Brain Research, 1033, 164-178.

Greenwood, B. N., Foley, T. E., Day, H., Burhans, D., Brooks, L., Campaeu, S., et al. (2004). Wheel running alters serotonin (5-HT) transporter, 5-HT(1a), 5-HT(1b), and alpha(1b)-adrenergic receptor mRNA in the rat raphe nuclei. Biological Psychiatry, 57, 559-568.

Greenwood, B. N., Foley, T. E., Day, H. E., Campisi, J., Hammack, S. H., Campeau, S., et al. (2003a). Freewheel running prevents learned helplessness/behavioral depression: Role of dorsal raphe serotonergic neurons. Journal of Neuroscience, 23, 2889-2898.

Greenwood, B. N., Foley, T. E., Day, H. E., Campisi, J., Hammack, S. H., Campeau, S., et al. (2003b). Freewheel running prevents learned helplessness/behavioral depression: Role of dorsal raphe serotonergic neurons. Journal of Neuroscience, 23, 2889-2898.

Grillon, C., Pellowski, M., Merikangas, K. R., \& Davis, M. (1997). Darkness facilitates the acoustic startle response in humans. Biological Psychiatry, 42, 453-460.

Hammack, S. E., Richey, K. J., Watkins, L. R., \& Maier, S. F. (2004). Chemical lesion of the bed nucleus of the stria terminalis blocks the behavioral consequences of uncontrollable stress. Behavioral Neuroscience, 118, 443-448.

Handley, S. L. (1995). 5-Hydroxytryptamine pathways in anxiety and its treatment. Pharmacology \& Therapeutics, 66, 103-148.

Harri, M., Lindblom, J., Malinen, H., Hyttinen, M., Lapvetelainen, T., Eskola, S., et al. (1999). Effects of access to a running wheel on behavior of C57BL/6J mice. Lab Animal Science, 49, 401-405.

Hays, W. L. (1988). Statistics. New York: Holt, Rinehart and Winston, Inc. Hillman, C. H., Belopolsky, A. V., Snook, E. M., Kramer, A. F., \& McAuley, E. (2004). Physical activity and executive control: Implications for increased cognitive health during older adulthood. Research Quarterly for Exercise \& Sport, 75, 176-185.

Hoyer, D., Clarke, D. E., Fozard, J. R., Hartig, P. R., Martin, G. R., Mylecharane, E. J., et al. (1994). International Union of Pharmacology classification of receptors for 5- hydroxytryptamine (Serotonin). Pharmacological Reviews, 46, 157-203.

Isaacs, K. R., Anderson, B. J., Alcantara, A. A., Black, J. E., \& Greenough, W. T. (1992). Exercise and the brain: Angiogenesis in the adult rat cerebellum after vigorous physical activity and motor skill learning [erratum appears in J Cereb Blood Flow Metab 1992 May;12(3):533]. Journal of Cerebral Blood Flow \& Metabolism: Clinical and Experimental, 12, 110-119.

Kennedy, S. L., Smith, T. P., \& Fleshner, M. (2005). Resting cellular and physiological effects of freewheel running. Medicine \& Science in Sports \& Exercise, 37, 79-83.

Kennett, G. A., Whitton, P., Shah, K., \& Curzon, G. (1989). Anxiogeniclike effects of mCPP and TFMPP in animal models are opposed by 5-HT1C receptor antagonists. European Journal of Pharmacology, 164, 445-454.

Kennett, G. A., Wood, M. D., Bright, F., Cilia, J., Piper, D. C., Gager, T., et al. (1996). In vitro and in vivo profile of SB 206553, a potent 
5-HT2C/5-HT2B receptor antagonist with anxiolytic-like properties. British Journal of Pharmacology, 117, 427-434.

Koch, M., Schmid, A., \& Schnitzler, H.-U. (1996). Pleasure-attentuation of startle is disrupted by lesions of the nucleus accumbens. Neuroreport, 7 , 1442-1446.

Laurin, D., Verreault, R., Lindsay, J., MacPherson, K., \& Rockwood, K. (2001). Physical activity and risk of cognitive impairment and dementia in elderly persons. Archives of Neurology, 58, 498-504.

Lee, Y., \& Davis, M. (1997a). Role of the hippocampus, the bed nucleus of the stria terminalis, and the amygdala in the excitatory effect of corticotropin-releasing hormone on the acoustic startle reflex. Journal of Neuroscience, 17, 6434-6446.

Lee, Y., \& Davis, M. (1997b). Role of the hippocampus, the bed nucleus of the stria terminalis, and the amygdala in the excitatory effect of corticotropin releasing hormone on the acoustic startle reflex. The Journal of Neuroscience, 17, 6434-6446.

Levita, L., Hammack, S. H., Mania, I., Li, X-Y., Davis, M., \& Rainnie, D. G. (2004). 5-hydroxytryptamine 1A-like receptor activation in the bed nucleus of the stria terminalis: Electrophysiological and behaviroal studies. Neuroscience, 128, 583-596.

Manger, T. A., \& Motta, R. W. (2005). The impact of an exercise program on posttraumatic stress disorder, anxiety, and depression. International Journal of Emergency Mental Health, 7, 49-57.

Meeusen, R., Thorre, K., Chaouloff, F., Sarre, S., De Meirleir, K., Ebinger, G., \& Michotte, Y. (1996). Effects of tryptophan and/or acute running on extracellular 5-HT and 5-HIAA levels in the hippocampus of fooddeprived rats. Brain Research, 740, 245-252.

Moraska, A., \& Fleshner, M. (2001). Voluntary physical activity prevents stress-induced behavioral depression and anti-KLH antibody suppression. American Journal of Physiology - Regulatory Integrative \& Comparative Physiology, 281, 484-489.

Morgan, W. P., \& Goldstein, S. E. (1987). Exercise and mental health. Washington, DC: Hemisphere Publishing Corporation.

Neeper, S. A., Gomez-Pinilla, F., Choi, J., \& Cotman, C. (1995). Exercise and brain neurotrophins. Nature, 373, 109.

Neeper, S. A., Gomez-Pinilla, F., Choi, J., \& Cotman, C. W. (1996). Physical activity increases mRNA for brain-derived neurotrophic factor and nerve growth factor in rat brain. Brain Research, 726, 49-56.

Overton, J. M., Kregel, K. C., Davis-Gorman, G., Seals, D. R., Tipton, C. M., \& Fisher, L. A. (1991). Effects of exercise training on responses to central injection of CRF and noise stress. Physiology \& Behavior, 49, 93-98.

Pietropaolo, S., Feldon, J., Alleva, E., Ciruli, F., \& Yee, B. K. (2006). The role of voluntary exercise in enriched rearing: A behavioral analysis. Behavioral Neuroscience, 120, 787-803.

Porter, R. H. P., Benwell, K. R., Lamb, H., Malcolm, C. S., Allen, N. H., Revell, D. F., et al. (1999). Functional characterization of agonists at recombinant human 5-HT2A, 5-HT2B and 5-HT2C receptors in CHO-K1 cells. British Journal of Pharmacology, 128, 13-20.

Radak, Z., Kaneko, T., Tahara, S., Nakamoto, H., Pucsok, J., Sasvari, M., et al. (2001). Regular exercise improves cognitive function and decreases oxidative damage in rat brain. Neurochemistry International, 38, 17-23.

Risbrough, V. B., \& Geyer, M. A. (2005). Anxiogenic treatments do not increase fear-potentiated startle in mice. Biological Psychiatry, 57, 33-43.

Salmon, P. (2001). Effects of physical exercise on anxiety, depression, and sensitivity to stress: A unifying theory. Clinical Psychology Review, 21, 33-61.

Samorajski, T., Delaney, C., Durham, L., Ordy, J. M., Johnson, J. A., \& Dunlap, W. P. (1985). Effect of exercise on longevity, body weight, locomotor performance, and passive-avoidance memory of C57BL/6 J mice. Neurobiology of Aging, 6, 17-24.
Schweimer, J., Fendt, M., \& Schnitzler, H. U. (2005). Effects of clonidine injections into the bed nucleus of the stria terminalis on fear and anxiety behavior in rats. European Journal of Neuroscience, 507, 117-124.

Scully, D., Kremer, J., Meade, M. M., Graham, R., \& Dudgeon, K. (1998). Physical exercise and psychological well being: A critical review. British Journal of Sports Medicine, 32, 111-120.

Shen, H., Tong, L., Balazs, R., \& Cotman, C. W. (2001). Physical activity elicits sustained activation of the cyclic AMP response element-binding protein and mitogen-activated protein kinase in the rat hippocampus. Neuroscience, 107, 219-229.

Singewald, N., Salchner, P., \& Sharp, T. (2003). Induction of c-Fos expression in specific areas of the fear circuitry in rat forebrain by anxiogenic drugs. Biological Psychiatry, 53, 275-283.

Soares, J., Holmes, P. V., Renner, K. J., Edwards, G. L., Bunnell, B. N., \& Dishman, R. K. (1999). Brain noradrenergic responses to footshock after chronic activity wheel running. Behavioral Neurosciecne, 113, 558-566.

Swain, R. A., Harris, A. B., Wiener, E. C., Dutka, M. V., Morris, H. D., Theien, B. E., et al. (2003). Prolonged exercise induces angiogenesis and increases cerebral blood volume in primary motor cortex of the rat. Neuroscience, 117, 1037-1046.

Thompson, B. L., \& Rosen, J. B. (2006). Immediate-early gene expression in the central nucleus of the amygdala is not specific for anxiolytic or anxiogenic drugs. Neuropharmacology, 50, 57-68.

Tong, L., Shen, H., Perreau, V. M., Balazs, R., \& Cotman, C. W. (2001). Effects of exercise on gene-expression profile in the rat hippocampus. Neurobiology of Disease, 8, 1046-1056.

van Praag, H., Christie, B. R., Sejnowski, T. J., \& Gage, F. H. (1999a). Running enhances neurogenesis, learning, and long-term potentiation in mice. Proceedings of the National Academy of Sciences, USA, 96, 13427-13431.

van Praag, H., Chunm, T. S., \& Gage, F. H. (2005). Exercise enhances learning and hippocampal neurogenesis in aged mice. The Journal of Neuroscience, 25, 8680-8686.

van Praag, H., Kempermann, G., \& Gage, F. H. (1999b). Running increases cell proliferation and neurogenesis in the adult mouse dentate gyrus [see comment]. Nature Neuroscience, 2, 266-270.

van Praag, H., Kempermann, G., \& Gage, F. H. (2000). Neural consequences of environmental enrichment. Nature Reviews Neuroscience, 1, 191-198.

Vaynman, S., Ying, Z., \& Gomez-Pinilla, F. (2004a). Exercise induces BDNF and synapsin I to specific hippocampal subfields. Journal of Neuroscience Research, 76, 356-362.

Vaynman, S., Ying, Z., \& Gomez-Pinilla, F. (2004b). Hippocampal BDNF mediates the efficacy of exercise on synaptic plasticity and cognition. European Journal of Neuroscience, 20, 2580-2590.

Walker, D. L., \& Davis, M. (1997). Anxiogenic effects of high illumination levels assessed with the acoustic startle paradigm. Biological Psychiatry, 42, 461-471.

Walker, D. L., \& Davis, M. (2002). Light enhanced startle: Further pharmacological and behavioral characterization. Psychopharmacology, 159, 304-310.

Walker, D. L., Toufexis, D. J., \& Davis, M. (2003). Role of the bed nucleus of the stria terminlalis versus the amygdala in fear, stress, and anxiety. European Journal of Pharmacology, 463, 199-216.

Wood, M. D. (2003). Therapeutic potential of 5-HT2C receptor antagonists in the treatment of anxiety disorders. Current Drug Targets-CNS \& Neurological Disorders, 2, 383-387.

Received November 30, 2007

Revision received February 8, 2008 Accepted February 12, 2008 